\title{
Case: ECJ - Courage v Crehan
}

\section{Judgment of the Court of 20 September 2001, Courage Ltd v Bernard Crehan and Bernard Crehan v Courage Ltd and Others, Case C-453/99, [2001] ECR I-6297}

Summary of the Judgment:

1. A party to a contract liable to restrict or distort competition within the meaning of Article 85 of the Treaty (now Article 81 EC) can rely on the breach of that provision to obtain relief from the other contracting party.

2. The full effectiveness of Article 85 of the Treaty (now Article 81 EC) and, in particular, the practical effect of the prohibition laid down in Article 85(1) would be put at risk if it were not open to any individual to claim damages for loss caused to him by a contract or by conduct liable to restrict or distort competition. Indeed, the existence of such a right strengthens the working of the Community competition rules and discourages agreements or practices, which are frequently covert, which are liable to restrict or distort competition.

Article 85 of the Treaty therefore precludes a rule of national law under which a party to a contract liable to restrict or distort competition within the meaning of that provision is barred from claiming damages for loss caused by performance of that contract on the sole ground that the claimant is a party to that contract.

However, in the absence of Community rules governing the matter, it is for the domestic legal system of each Member State to designate the courts and tribunals having jurisdiction and to lay down the detailed procedural rules governing actions for safeguarding rights which individuals derive directly from Community law, provided that such rules are not less favourable than those governing similar domestic actions (principle of equivalence) and that they do not render practically impossible or excessively difficult the exercise of rights conferred by Community law (principle of effectiveness).

Under those conditions, Community law does not preclude national law from denying a party who is found to bear significant responsibility for the distortion of competition the right to obtain damages from the other contracting party. Under a principle which is recognised in most of the legal systems of the Member States and which the Court has applied in the past, a litigant should not profit from his own unlawful conduct, where this is proven.

In particular, it is for the national court to ascertain whether the party who claims to have suffered loss through concluding a contract that is liable to restrict or distort competition found himself in a markedly weaker position than the other party, such as seriously to compromise or even eliminate his freedom to negotiate the terms of the contract and his capacity to avoid the loss or reduce its extent, in particular by availing himself in good time of all the legal remedies available to him.

* The full text of the judgments is available at http://europa.eu.int/eur-lex/en/search/ search_case.html. 


\section{Case Note}

\section{Introduction}

In Courage the European Court of Justice has recognised that any individual - including a party to a restrictive contract - can claim compensation for loss caused by a violation of Article 81or 82 EC. The Courage judgment builds on the Francovich case law on state liability for violations of Community law. ${ }^{1}$ Courage does not expressly state that the right of an individual to claim damages in case of competition law violations has a Community law basis, although the author submits, with others, that it has. One thing is sure: this right is also vested in an individual who suffers from a competition law violation by the conclusion of a contract to which he or she is a party. The Court reacts to a limitation that existed under English contract law.

Present initiatives at the EC level and recent legislation in some Member States (like the UK and Germany) aim at granting individuals specific rights to compensation in case of competition law violations. Provisions of some other existing competition laws need to be reconsidered in the light of Courage (as a judgment of the Italian Supreme Court of 2002 illustrates).

The present case note will focus on the consequences of Courage for contract law. The case raises questions as to the traditional distinction between contractual and extra-contractual liability. Competition law blurs that distinction.

\section{The preliminary reference and its legal context}

In 1991 Crehan, the tenant of a pub, had agreed with Courage, a brewery with $19 \%$ share of the market in sales of beer and owning the premises, to purchase beer exclusively from Courage. In 1993 Courage brought an action for the recovery of $£ 15,000$ for unpaid deliveries of beer. Crehan's defence was that the exclusive purchase obligation was contrary to Article 81 para 1 EC (the prohibition of restrictive agreements and practices which adversely affect trade between Member States) and he counter-claimed for damages. Mr. Crehan contended that Courage sold its beers to independent tenants of pubs at substantially lower prices than to himself. The price difference, he contended, drove him out of business.

1 Joined Cases C-6/90 and C-9/90 Francovich and Others [1991] ECR I-5357 (ECJ) and subsequent case law, see summarising this case law and the case law on non contractual liability of the institutions: Case C-352/98 Laboratoires pharmacuetiques Bergaderm [2000] ECR I-5291 (ECJ). 
The Court of Appeal of England and Wales considered that English law did not allow a party to an illegal agreement to claim damages from the other party, but wondered whether that rule was compatible with Community law.

\section{The Opinion of the Advocate General}

Advocate General Mischo delivered his opinion on 22 March 2001. A first question put by the Court of Appeal was whether a correct interpretation of Article 81 EC could exclude a contract party from relying, in court, on Article $81 \mathrm{EC}$ to seek relief from the other party. This question could easily be dealt with: Article 81 EC constitutes a fundamental provision the useful effect of which would be frustrated if it could not be relied upon by a co-contractor.

As to the question whether a party to a contract can claim compensation if the contract violates Article $81 \mathrm{EC}$, the Advocate General first recalled that it is settled case-law that Article 81 EC produces direct effects in relations between the individuals concerned which the courts must safeguard. ${ }^{2}$ This includes the right, for individuals, to be protected from the harmful effects that an agreement which is automatically void may create. ${ }^{3}$ The individuals who can benefit from such protection are, of course, primarily third parties, that is to say consumers ${ }^{4}$ and competitors who are adversely affected by a prohibited agreement. ${ }^{5}$ Parties to the agreement cannot normally benefit form the same protection because they are the cause of the agreement. This is by virtue of the application of a principle of law, recognised in most developed legal systems, including the Community system, according to which a party may

2 Case 127/73 BRT v Sabam [1974] ECR 51 (ECJ); Case C-234/89 Delimitis v Heninger Bräu [1991] ECR I-935 (ECJ); this holds a fortiori since the entry into force of Regulation $1 / 2003$. Pursuant to this new implementing regulation Article 81 EC can be applied as a whole by national courts and authorities. 'Declarations of inapplicability' for agreements satisfying the conditions of art 81 para 3 - ie restrictive practices which generate certain advantages, while passing a fair share thereof to consumers and provided they do not contain any restriction which is not indispensable and do not substantially eliminate competition - are not subject anymore to a notification to and a decision by the Commission.

3 Point 37 of the opinion.

4 For consumers claiming compensation for loss suffered as a result of eg a cartel may be very difficult: see the passing on problem under paragraph 5.1 .

5 With reference to the opinion of Advocate general van Gerven in Case C-128/92 Banks [1994] ECR I-1209, points 43 et seq (ECJ), who was the very first to advocate a Community right to damages for victims of infringements of the European competition rules. 
not profit from its own wrong. ${ }^{6}$ However, the fact of being a party to the agreement infringing Article $81 \mathrm{EC}$ does not amount in all circumstances to a wrong. The criterion is whether the party bears responsibility for the distortion of competition. If that responsibility is not significant (like that of a pub owner who is too small to resist the economic pressure of the other party, the brewery), there is no reason to deny that party the protection of Article 81 EC. Therefore Community law precludes a rule, as in English law, which prevents a party subject to a clause in a contract which infringes Article 81 EC from recovering damages for the loss suffered by it on the sole ground that it is a party to that contract.

\section{The judgment of the Court}

The ECJ followed the Advocate General. The Court recalled that the Treaty has created its own legal order. Community law is intended to give rise to rights to individuals. Community law has precedence. ${ }^{7}$ Article 81 EC is a fundamental provision that is essential for the functioning of the internal market. Evidence of this can be found in Article 81 para 2 EC: an agreement contrary to this provision is automatically void. ${ }^{8}$ An agreement that is null and void by virtue of Article 81 para $2 \mathrm{EC}$ has no effect as between the contracting parties and cannot be set up against third parties. ${ }^{9}$ Moreover, it is capable of having a bearing on all the effects, either past or future, of the agreement or decision concerned. ${ }^{10}$ Finally, the Court recalled that it has held that Articles 81 para 1 and $82 \mathrm{EC}$ (the prohibition of abuse of a dominant position) produce direct effects in relations between individuals and create rights for the individuals concerned which the national courts must safeguard. ${ }^{11}$

It follows from the foregoing considerations, that any individual can rely on a breach of Article 81 para 1 EC ${ }^{12}$ before a national court, even where he is a

6 The Advocate general refers to Case C 39/72 Commission v Italy [1973] ECR 101, paragraph 10 (ECJ) and the nemo auditor propriam turpitudinem allegans principle in the Opinion of A. G. Cosmas in joined Cases C-177/99 and C-181/99 Ampafrance and Sanofi [2000] ECR I-7013, points 49 and 83 (ECJ) and his opinion in Case C-386/89 Crispolton [1991] ECR I-3695, point 46 (ECJ).

7 See paragraph 19 of the Judgment.

8 With reference to Case C-126/97 Eco Swiss [1999] ECR I-3055, paragraph 36 (ECJ).

9 With reference to Case 22/71 Béguelin [1971] ECR 949, paragraph 29 (ECJ).

10 With reference to Case 48/72 Brasserie de Haecht II [1973] ECR 77, paragraph 26 (ECJ).

11 Case 127/73, n 2 above, paragraph 16; Case C-282/95 P Guérin Automobiles v Commission [1977] ECR I-1503, paragraph 39 (ECJ).

12 Since the entry into force of Reg $1 / 2003$, article $1 / 2003$ (including the third paragraph) seems to be directly effective as a whole (see also $\mathrm{n} 2$ ). 
party to a contract that is liable to restrict or distort competition within the meaning of that provision. ${ }^{13}$

As regards the possibility of seeking compensation for the loss caused by a contract or by conduct liable to restrict competition, the Court recalled that national courts must ensure that provisions of Community law within their jurisdiction take full effect and must protect the rights which they confer on individuals ${ }^{14}$ ('effet utile' principle). The full effectiveness of Article 81 EC would be put at risk if it were not open to any individual to claim damages for loss caused to him by a contract or by a conduct liable to restrict competition. ${ }^{15}$ Actions for damages can indeed make a significant contribution to the maintenance of effective competition in the Community.

There should not therefore be any absolute bar to such an action being brought by a party to a contract or to conduct liable to restrict competition. ${ }^{16}$

However, the Court immediately recalled the procedural autonomy of the Member States, ie the right to lay down the procedural rules for bringing such actions, subject to the respect of the principles of equivalence (ie these rules should not be less favourable than those governing similar domestic actions) and effectiveness (ie these rules should not render impossible or excessively difficult the exercise of the rights conferred by Community law). ${ }^{17}$ In that context the Court has already held that Community law does not prevent national courts from taking steps to ensure that the protection of the rights guaranteed by Community law does not entail the unjust enrichment of those who enjoy them. ${ }^{18}$ Similarly, the Court conceded that provided the principles of equivalence and effectiveness are respected, Community law does not preclude national law from denying a party who has significant responsibility for the distortion of competition the right to obtain damages from the other contracting party. 'Under a principle which is recognised in most of the legal systems of the Member States and which the Court has applied in the past (see Case 39/72 Commission v Italy [1973] ECR 101, paragraph 10], a litigant should not profit from his own unlawful conduct, where this is proven.' 19

13 Paragraph 24 of the judgment.

14 Paragraph 25 of the judgment with reference to Case 106/77 Simmentahl [1978] ECR 629, paragraph 16 (ECJ) and Case C-213/89 Factortame [1990] ECR I-2433, paragraph 19 (ECJ).

15 Paragraph 26 of the judgment.

16 Paragraphs 27 and 28 of the judgment.

17 Paragraph 29 of the judgment.

18 Paragraph 30 of the judgment with reference to ia joined Cases C-441/98 and C-442/98

Michaïlidis [2000] ECR I-7145, paragraph 31 (ECJ).

19 Paragraph 31 of the judgment. 
In that regard the matters to be taken into account by the judge include the economic and legal context in which the parties find themselves and the respective bargaining power and conduct of the two parties to the contract. One of these factors is whether the party claiming damages was in a markedly weaker position than the other party, such as seriously to compromise his freedom to negotiate the terms of the contract. ${ }^{20}$ Such will be that case where the other party controls a network of similar contracts which have a cumulative effect on competition and imposes the terms of the contract on the party claiming damages. ${ }^{21}$

It is interesting, but probably disappointing, to learn that in its judgment after this preliminary reference the High Court denied, on factual grounds, any claim of injury by Mr Crehan, without even mentioning the ECJ judgment. ${ }^{22}$

\section{Comments}

\section{The 'Courage' doctrine}

Courage can be interpreted as the recognition by the ECJ of a principle of a Community right ${ }^{23}$ to damages for victims of infringements of the EC competition rules. The Court indeed stresses that the full effectiveness of the competition rules requires Member States to grant any individual to claim damages for loss caused to him by a contract or by a conduct liable to restrict competition.

Paradoxically, by focusing on its rejection of the English rule which denies a party to an unlawful contract in all circumstances the right to claim damages from the other party, and thus including parties to the unlawful contract in the circle of beneficiaries of the right to claim damages, the ECJ has not clarified the concept of 'any individual' in a non contractual situation, which in itself does not raise the same questions, thus leaving some doubt as to whether this expression includes eg consumers to whom the prejudice suffer-

20 Paragraph 33 of the judgment.

21 Paragraph 34 of the judgment.

22 N. Reich, 'The "Courage” Doctrine: encouraging or discouraging compensation for antitrust Injuries?’, (2005) 42 Common Market Law Review 35 et seq, 39.

23 In this sense: W. van Gerven, 'Substantive remedies for private enforcement of EC antitrust rules before national courts', in J. Stuyck / H. Gilliams (eds), Modernization of European Competition Law (Antwerp: Intersentia, 2002); A. Kominos, 'New prospects for private enforcement of EC Competition law', (2002) 39 Common Market Law Review 473; Reich, n 22 above, 38. 
ed by innocent members of customers of a cartel have been passed? ${ }^{24}$ It is submitted that, as a matter of principle, they are included. Nevertheless many questions remain. ${ }^{25}$ Particularly important for consumers is the well known discussion in competition law of 'passing on', which can be used as a defence by the undertakings faced with a claim for damages for infringement of the competition rules, especially price cartels or abuse of a dominant position by the charging of excessive prices. Where the plaintiff is, for example, a retailer, the defendant will argue that the plaintiff will have passed the surcharge paid on to customers, ie the consumers. This defence was considered possible in Denmark, Germany and Italy. ${ }^{26}$ If this is so, one could be tempted to infer from it that the final consumer should be in a good starting position to claim damages, but for want of adequate procedures (such as class actions) consumers do not seem, to date, to have been successful in claiming damages for competition law infringements. ${ }^{27}$ Moreover, although the national reporters in the study by Waelbroeck, Slater \& Even-Soshan ${ }^{28}$, agree on the theoretical possibility for indirect purchasers to bring claims, they mention that the lack of clarity on this point, the difficulties in proving the causal link, and the existence of the 'passing on' defence bring into question the practical possibilities for such claims. Suggestions for facilitating claims by indirect purchasers ranged from clarification of the law to ensure standing rights of indirect purchasers to the creation of a specific legal basis for indirect purchasers to bring claims. A recent judgment of the Italian Corte di Cassazione shows that actions for damages by final consumers in case of violations of the competition rules may be rendered difficult by rules on jurisdiction and by questions on the precise qualification of the action (action in tort on the basis of Article 2043 Codice civile (C.c.) or Article 1337 C.c.: culpa in contrahendo?). ${ }^{29}$

\section{Contract law aspects}

The consequences of Courage for tort actions have been analysed by Norbert Reich. ${ }^{30}$ In these comments I would like to address some consequences for contract law.

24 See also Reich, n 22 above, 38-39.

25 See Reich, n 22 above, 38-39.

26 See D. Waelbroeck / D. Slater / G. Even-Soshan (eds), Study on the Conditions of Claims for damages in Case of Infringement of EC Competition Rules (Brussels, 2004) (available on the web site of DG Comp).

27 Waelbroeck / Slater / Even-Soshan, n 26 above, 10.

28 Ibid, 10.

29 F. Afferni / F. Wenzel Bulst, 'Kartellrechtliche Schadensersatzansprüche von Verbrauchern' (case note: Corte di Cassazione, 9 December 2002) Zeitschrift für Europäisches Privatrecht 2005, 143 et seq, 150-151.

30 Reich, n 22 above. 
One contract law aspect has been addressed by the judgment: a national rule cannot per se exclude the right of a party to a contract violating Article $81 \mathrm{EC}$ to claim damages from the other party, but the Court has recognised that national law can limit that right on the basis of the principle that a party should not benefit from its own wrongdoing. I will come back to that question hereinafter (see V 2 d) 'nemo auditor').

For the rest the Court does not give a lot of guidance. What does the consideration that Member States have to grant any individual to claim damages for loss caused to him by a contract or by a conduct liable to restrict competition mean for contract law?

I shall first turn to the nature of contractual loss in case of competition infringements (V 2 a)) and the problem of causation (V 2 b)). Thereafter I shall briefly examine the problems which can arise under national law deriving from the distinction between actions for damages ex contractu and actions for damages ex delicto (V 2 c)).

a) nature of the contractual loss

In particular the question arises what kind of claim for damages can be brought by a contract party under the Courage doctrine?

A first, classic, hypothesis, is that of non-performance. ${ }^{31}$ A claim for damages for non-performance will obviously not be based on a violation of the competition rules. On the other hand, where a claim for damages for non-performance is brought by a party to a contract, the defendant party can invoke the nullity of the clause (or as the case may be of the contract) that violates the competition rules to justify his refusal to perform. This raises the question whether the 'guilty' party should be barred from such a defence. The answers given to that question may differ from Member Sate to Member Sate (see V 2 d)).

Courage did not concern a claim for damages for non performance. ${ }^{32} \mathrm{Mr}$. Crehan, the pub owner, brought a counter claim for damages based on a prejudice caused by an obligation to buy beer exclusively from Courage at prices

31 See Art 9:501 of the Principles of European Contract law: Art 9:501 (ex Art 4.501): Right to Damages: (1) The aggrieved party is entitled to damages for loss caused by the other party's non-performance which is not excused under Article 8:108; (2) The loss for which damages are recoverable includes: (a) non-pecuniary loss; and (b) future loss which is reasonably likely to occur.

32 In the Courage case Mr. Crehan refused to pay for the deliveries invoking that the beer tie was contrary to Art $81 \mathrm{EC}$. 
which drove him out of business (because his competitors could buy the same beer at lower prices).

This raises the question of what kind of loss Crehan was asking compensation for. Obviously it was not a loss caused by the tie-in (the clause which was allegedly contrary to Article $81 \mathrm{EC}$ in itself), but the fact that the tie-in prevented him from escaping from a contract which imposed too high prices in comparison with competitors.

In other words, the tie-in was not by definition a clause causing damage and the damage was not solely caused by the tie-in, but by the tie-in and the circumstances external to the contract. This is not surprising in competition matters. Article $81 \mathrm{EC}$ prohibits agreements restricting competition, ie, according to present insights, agreements which effectively (and not merely formally) restrict competition in the market. For each agreement an economic appraisal has to be made, unless there is a group exemption. Vertical restrictions, such as those in the Courage case are largely exempted under Regulation 2790/1999 if the market share of the supplier in the relevant market does not exceed $30 \%$, but certain clauses are black-listed, meaning that they are not automatically exempted and will generally not benefit from a positive appraisal. This is eg the case with an exclusive purchasing obligation, as in Courage (see Article 5 of Regulation 2790/1999), if it is not concluded for a definite period not exceeding five years. In other words where a supplier with a market share of not more than $30 \%$ imposes on its distributor an exclusive purchasing obligation for a definite period of not more than five years, the clause is per se compatible with Article $81 \mathrm{EC}$, although in fact it does restrict competition and may cause a competitive prejudice to a distributor, eg a distributor having to pay a higher price for the products than (some of) its competitors, as the case may be without objective justification for that unequal, ie discriminatory, treatment. If the supplier is not dominant, he is not under an obligation to treat his distributors equally.

Thus Courage also raises questions regarding causation. They will be addressed hereinafter (see V 2 b)).

In the case of a restrictive agreement contrary to Article 81 EC or Article 82 $\mathrm{EC}^{33}$ (or the national equivalents of these articles), a party to that agreement may suffer from various kinds of losses depending on the nature of the agree-

33 Art 82 EC prohibits abuse of a dominant position, which is usually unilateral conduct.

However, in Ahmed Saeed (Case C-66/86 [1989] ECR 803 [ECJ]) the ECJ decided that Art 82 EC can apply to an agreement contrary to Art 81 EC, namely where one of the parties is dominant and abuses that position by imposing unfair contract terms on the other. 
ment and of the restrictive clause or practice. In the case of a distributorship agreement, the distributor may eg suffer direct pecuniary loss as a result of excessive or discriminatory prices imposed by a supplier in a dominant position (violation of Article $82 \mathrm{EC}$ ). A party to a horizontal illegal market sharing agreement may suffer a loss of business opportunities (and hence of turnover) as a result of the faithful execution of the agreement. A distributor, again, may suffer a loss by complying with an illegal export ban in a distributorship agreement. In all these cases the loss is likely to be directly caused by the competition infringement, although, here again, the causal link between loss and infringement may be difficult to establish. In the case of an export ban some loss may be relatively easy to establish on the basis of orders from abroad that the distributor was not entitled to honour, but how can the entire sum of the lucrums cessans, the lost opportunities, including the orders which were not made because of the existence of a closed distribution system (which according to national contract law would generally also be covered), be established?

\section{b) Causation}

A person claiming damages has to prove the existence of a causal link between the generating fact (the tortious conduct, the non performance of a contract, the insertion of an anti-competitive clause in the contract, and so on) and the loss he has suffered. It is well known that there is not one single theory of causation in European contract law. Courage does not address this question. The Francovich case law on which the Courage doctrine is (partly) based and which could therefore serve as source of inspiration hardly gives any guidance. In addition, in contract law causation is rarely an issue: the aggrieved party is entitled to damages fro the loss caused by the other's party's non-performance. Loss caused by a violation in contractu of the competition rules is more like loss caused in tort.

c) Contract and tort - contractual and extra-contractual damages

In the absence of a uniform concept of contract law in Europe, there is no clear dividing line between contract law and tort law. ${ }^{34}$ In addition, in some legal systems there are rather strict rules on the separation between actions for damages ex contractu and actions for damages ex delicto. This is eg the

34 See C. von Bar / U. Drobnig, Study on Property Law and Non-contractual Liability Law as they relate to Contract Law, Submitted to the European Commission Health and Consumer Protection Directorate-General, SANCO B5-1000/02/000574, paragraph 19. 
case in French law (and in Belgian) law, but not or less so in German and English law. ${ }^{35}$ Under French and Belgian law a claim for damages based on tort law will be rejected where the alleged fault and damage are purely contractual, in the sense that in the absence of a contract there would have been no fault or damage. Courage does not make that distinction - and there was certainly no reason to do so.

An action for damages for violation of competition law by a contract party is not an action for non-performance, although, as in the case of Mr. Crehan, the loss may be primarily caused by the existence of a contract. The fault is contractual and non-contractual. The loss is in a sense purely contractual (had Mr. Crehan not be bound by the tie-in he could have avoided the loss as a result of too high prices).

Many implementing provisions of Article 81 EC (such as black listed clauses in block exemption regulations) are purely contractual, ie they do not envisage the violation of Article 81 EC absent an agreement (eg a 'concerted practice').

Courage shows that actions for damages by parties to a contract violating the competition rules put into question the divide between contract and tort.

\section{d) 'Nemo auditor'}

In Courage the ECJ has clearly decided that national law should not bar as such a party to a contract to claim damages for violations of EC competition law. However the Court recognises the principle existing in most legal systems that a litigant should not profit from his own unlawful conduct. The Court also accepts that national law denies a party to an anti-competitive contract the right to obtain damages from the other party where he has 'significant responsibility for the distortion of competition'. The question thus arises whether the ECJ has not solely recognised the 'nemo auditor' principle to the extent that it bars a party to an anti-competitive contract who bears 'significant responsibility' for the distortion of competition to claim damages from the other party? Could 'nemo auditor' as it is understood in the common tradition of the Member States (assuming that the right to claim damages for violations of Article 81 and $82 \mathrm{EC}$ is a Community law right) or in the national law applicable (assuming that that right is merely national) still be invoked where it would lead to rejecting a claim for damages by a party who

35 See H. Beale / A. Hartkamp / H. Kötz / D. Tallon (eds), Cases, Materials and Text on Contract Law, Ius Commune Casebooks on the Common Law of Europe (Oxford: Hart Publishing, 2002) 69-70; von Bar / Drobnig, n 34 above, paragraph 280 et seq. 
has only an insignificant responsibility in distorting competition (while he may have had a much heavier responsibility in the shaping of the contract and would on that ground have to face 'nemo auditor')? And, finally: what is 'significant responsibility'? It is for the ECJ to clarify these questions when they arise.

\section{Concluding remarks}

Courage has established two important principles: 1) a victim of conduct which violates Article 81 or $82 \mathrm{EC}$ has a right to damages and 2) this right is also given to a party to a contract violating Article 81 EC who does not bear significant responsibility for that violation. Subject to the principle mentioned under 2), Courage also recognises 'nemo auditur'. The question whether the right thus conferred on victims of violations of Articles 81 and $82 \mathrm{EC}$ is a Community law right or a right which the Member Sates have to grant under national law is not decided. Many other questions remain. In particular Courage raises the question to what extent principles and rules of contract law will and can play a role in the design of this right to damages, which rather seems to have a tort law basis.

Jules Stuyck, Professor of European and Economic law, K.U.Leuven and R. U. Nijmegen, Partner Liedekerke. Wolters. Waelbroeck. Kirkpatrick, Brussels 